\title{
DEFENCE HERITAGE OF THE SPANISH CIVIL WAR: PRESERVATION OF AIR-RAID SHELTERS IN VALENCIA
}

\author{
M.T. BROSETA PALANCA \\ Instituto Universitario de Restauración del Patrimonio, Universidad Politécnica de Valencia, España
}

\begin{abstract}
When addressing historical heritage, the reasons for architecture preservation are rarely questioned. However, reasons must be justified when contemporary war heritage is discussed in our immediate context. In the European countries that suffered most severely from World War II, war remains are preserved as rebuilding elements: once the confrontation has passed, the traces are used to analyse the causes in order to avoid new conflicts in the future. The scientific study and dissemination of war heritage in Spain has become a social commitment, not undertaken by public administrations but by civic proponents who do not want to forget and who work to preserve the culture of peace.

The construction of air-raid shelters during the Spanish Civil War (1936-1939) was an important task carried out by the Passive Defence Committees, demonstrating that civil society organized against the war. Because of citizen pressure and studies performed by a few researchers, after many years of neglect or even demolition, some shelters have been completely or partially saved and listed in the Municipal Heritage Catalogue as Local Heritage, which recognizes their undeniable historical value and the need for preservation established by the Cultural Heritage Law.

In regard to the global framework of war heritage preservation, four phases must be conducted: data gathering and listing, the adoption of protection measures, investment in refurbishment and reuse and finally the dissemination of results. This article provides a view of the first two phases implemented on Valencian air-raid shelters, following a research structure that includes the study of war heritage to establish its meaning and value, the understanding of legal documents regarding protection, research into preservation and reuse performance in other scopes, field study and data gathering as well as the proposals for the next phases of protection and reuse.

Keywords: air-raid shelters, protection, Spanish Civil War, war heritage.
\end{abstract}

\section{INTRODUCTION}

Although the preservation standards for defence elements as cultural assets originated in the second half of the 18th century, the defence of contemporary war heritage appeared in the years following World War II. And in the case of Spain, due to the singular and especially painful memory of the Civil War (1936-1939), the acknowledgement, restoration and reuse occurred even later, at the end of 20th and the beginning of the 21st century, through a slow and uneasy process, which is now starting to yield positive results.

Within the limited space of this article, today's state of affairs in Spain is summarized, highlighting the most significant recent cases of war heritage in our country, and more precisely, the process of protection and valuation of air-raid shelters in the city of Valencia, which has changed its appreciation criteria, reaching a high level of administrative protection through Local Assets of Cultural Interest regulations, stated in Law 4/1998, June 11th, regarding Valencian cultural heritage.

\section{THE SPANISH CIVIL WAR HERITAGE}

The Spanish Civil War is an exceptionally meaningful milestone that marks the country's historical evolution in the second half of the 20th century. It is in fact the most written about war event after World War II and was the training field for the future battles of World War II: 
Italian and German Condor aircraft participated on the Mediterranean coast. Nevertheless, little about the human reality of this period is known.

The reason why this part of history must be protected, sometimes needs to be justified, because for a long period there was an aim of forgetting the tragedy, but once this process had been completed, war heritage had to be considered as a cultural resource with educational and instructional value and could not be lost due to indolence: 'forgetting may be necessary, but the destruction of memory is self-mutilation' [1]. An entire generation had no knowledge of the war from a scientific point of view and gained their perspectives from the slanted views of artistic productions.

Sometimes in young towns, war heritage is the only visible cultural resource able to create identity ties in their population. For instance, the Association of Historical Memory Spaces was established in 2006 in the township of Rivas Vaciamadrid (Madrid), for the preservation, refurbishment and transmission of the cultural heritage of the Battle and Front of Jarama, with dissemination activities for many kinds of audiences including schools, youth groups and families [2].

The best demonstrations of public interest in war heritage preservation are the local claims that have occurred until now, and which still continue, in defence of the most recognizable examples. A neighbouring platform in 1999 achieved the archaeological exploration of the Diamant Square shelter. And another one, carried out by a group of historians, saved a part of the Revolució Square shelter (1994), both in Barcelona. The neighbours of Ruzafa (Valencia) fought in vain to save their shelter. In Cáceres, Adenex (Association for the Defence of the Nature and Resources of Extremadura, Spain) has been fighting from 2009 for the preservation of the air-raid shelters in the old city aerodrome.

\subsection{The scientific-technical treatment of war heritage}

According to the thesis of Santacana, there are four basic rules for war heritage treatment from a scientific-technical point of view:

1. War heritage is unique and cannot be broken up, nor an important part of it be excluded.

2. The remains of a recent war are part of the collective heritage of nations. This is a valid and respected norm across Europe.

3. What can be shown or not cannot be decided under any excuse or fallacy. Nobody must become a censor of what is acceptable or not, regarding the past of nations.

4. What is extracted from the soil with scientific aims must only be obtained through archaeological techniques. Last century's war knowledge requires the systematic use of archaeology.

The Civil War heritage is diverse throughout Spain's territory. This is what characterizes it and there is no single dominant trace, but elements separated in each zone of conflict. Present structures in a territory are direct samples of battles: trenches, parapets, nests for machine guns, small forts, squad posts, tunnels, latrines, etc. Other remains in the background also complete this heritage: jails, roads, railways, factories and other supporting structures.

Some experts defend zoning as a necessary tool of war heritage research. The zoning of different war scenarios in units and subunits allows the inclusion of local studies in larger scopes, where a wider perspective provides a global assessment [3]. 


\subsection{Legal framework of protection}

A critical step towards the new valuation of these recent past elements was the approval of the Defensive Architecture National Plan, where heritage from the 20th century is classified [4].

Civil War heritage recognition is stimulated by the Historical Memory Law (Law 52/26 December 2007). This historical period is given the social importance requested by social groups and associations. The law's main contribution, from the perspective of material war heritage, is its support for the collaboration between institutions, for the elaboration of a catalogue of Civil War and dictatorship heritage.

With similar objectives, the Government of Andalusia (Spain) approved in 2011 the figure of Historical Memory Places and their catalogue, in order to defend them as elements of the community's cultural identity and legacy for the learning of democratic values.

Consequently, months later, fourteen new Historical Memory Places were declared, through the agreement of 20 March 2012, followed by one on 27 December 2013, which specified 34 new locations. Most of these sites are a way of recognizing people who suffered violence, persecution or imprisonment. Additionally, front- and rear-line defence architecture heritage is also included: the Castel of San Sebastian in Cadiz, the air-raid shelter of Jaen (on Santiago Square and the old Hospital of San Juan de Dios) and the remains of the Lopera Battle were all declared in 2012. In turn, the air-raid shelters of Almería, the Valsequillo Battlefield and the Granada Siege and its defensive structures were declared in 2013.

However, the legal framework of preservation of war heritage did not change significantly with this law, as protection tools were already adequate: the archaeological zones can include a substantial part of the heritage, or they could be protected by other categories in Heritage Law (natural or cultural parks). In the case of the main heritage, it could be protected by other figures with better control. In fact, collecting it in urban catalogues or heritage inventories is typical. Therefore, there are no legal figures remaining, but the need to include war heritage in our legal system persists.

\subsection{Preservation of air-raid shelters}

The important cultural value of air-raid shelters as a part of war heritage lies in its representation of a civil society organized against the war [5]. Regarding their heritage value, they are the most attractive of war remains, because they are situated in urban areas and are large enough for people to enter, which makes them easy to visit. However, they involve undesirable conditions with respect to location and access.

Sometimes due to ignorance, and in other cases because of a lack of preservation, part of this heritage has been destroyed, although popular pressure and civil societies have completely or partially saved some evident examples. A good example to be followed would be the proper treatment given to air-raid shelter 307 in Poble Sec (Barcelona), where a deep analysis was conducted regarding the way in which civilians defended themselves from air attacks.

In recent years, notable efforts have been made in terms of the refurbishment and public opening of air-raid shelters in Spain, as well as shelter 307 in Barcelona. Other representative examples include Alicante (shelter 46 on Balmis Square), Albacete (Altozano shelter), Jaen (Santiago Square and Villacarrillo), Murcia (shelter 633), Santander (Prince Square), Almería (1 km underground, a shelters' route), Santa Margarida i els Monjos (air-raid shelters' route 
in Penedés), La Garriga (Station shelter), Reus (Patacada shelter), and other examples in Villanueva del Duque (Córdoba), Vega de Tembleque (Toledo) and Alcañiz (Teruel).

The Valencian Cultural Administration management has been firm and constant in the defence of war heritage. Not only trenches, but other defensive elements can be visited and are maintained in a good state of preservation, although the required heritage catalogue is not yet available for the precise analysis of their features, location and state of preservation.

Alcoy, Bañeres, Alacuás, Cullera, Carcaixent and Ribarroja (air-raid shelters), Nules and Paterna (bunkers) and Villavieja and El Puig (fortifications) are useful examples that can already be seen to follow the advice included in the report entitled 'Civil War Heritage Preservation (1936-1939)', of 20 December 2004, issued by the Valencian Cultural Council, a competent administration in terms of cultural heritage.

The common point among the various investigations regarding air-raid shelters is the use of three resources within their methodology: archive documents, oral tradition and urban archaeology, which is demonstrated in the research carried out on air-raid shelters in the city of Valencia.

\section{AIR-RAID SHELTERS IN THE CITY OF VALENCIA}

The conclusions of the research conducted on the construction of shelters were extensively described in the work of architect Taberner [6], and in the publication of Taberner and Broseta [7], which developed the research on this issue, initiated in a technical report for the Council of Valencia in 2002 for the purpose of elaborating a catalogue of shelters. In the same way, other researchers have contributed to the identification and location of shelters around the city: Aragó et al. [8], Vera Deleito A. and Vera Deleito J. [9] and Moreno and Muñoz [5].

The documentation for this research came from the Municipal and Historical Archive of Valencia (MHAV), where there are nine boxes with plans and files related to the subject of shelters. Forty building permissions for private shelters have been found in the municipal archive of urban permits, in boxes that belonged to the Expansion Zone and Urban Licenses Department from 1936 to 1939. In addition, the same number of public shelters, mostly built in schools, has been found. However, the documents in the archive do not gather all the shelters we know about; no statement or agreement by the Passive Defence Committee, nor a complete list with the number and location of the shelters, has appeared.

Moreover, there are interesting administrative files regarding the shelters, but little constructive information: barely half a dozen shelter plans and often imprecise data with no street numbers or even street names. For this reason, some constructions could not be located.

In addition to the municipal files, newspapers and library periodicals have been reviewed, including Fragua Social (1937 and 1938) and the almanac Las Provincias (1940), where the three years worth of newspapers are collected.

The plan of the township of Valencia, consisting of 394 pages, is found in the Historical Archive of the College of Architecture of Valencia [10], where the location and layout of some shelters are specified. Apart from this, no more graphic information exists.

\subsection{Construction}

From November 1936 to October 1937, the city of Valencia was the capital of the Spanish Republic, in the difficult circumstances generated by the Civil War, where air raids had a novel and prominent role, even more influential than commonly thought. The bombing suffered by the city, from the sea and air, brought as a consequence defence measures for protection of 


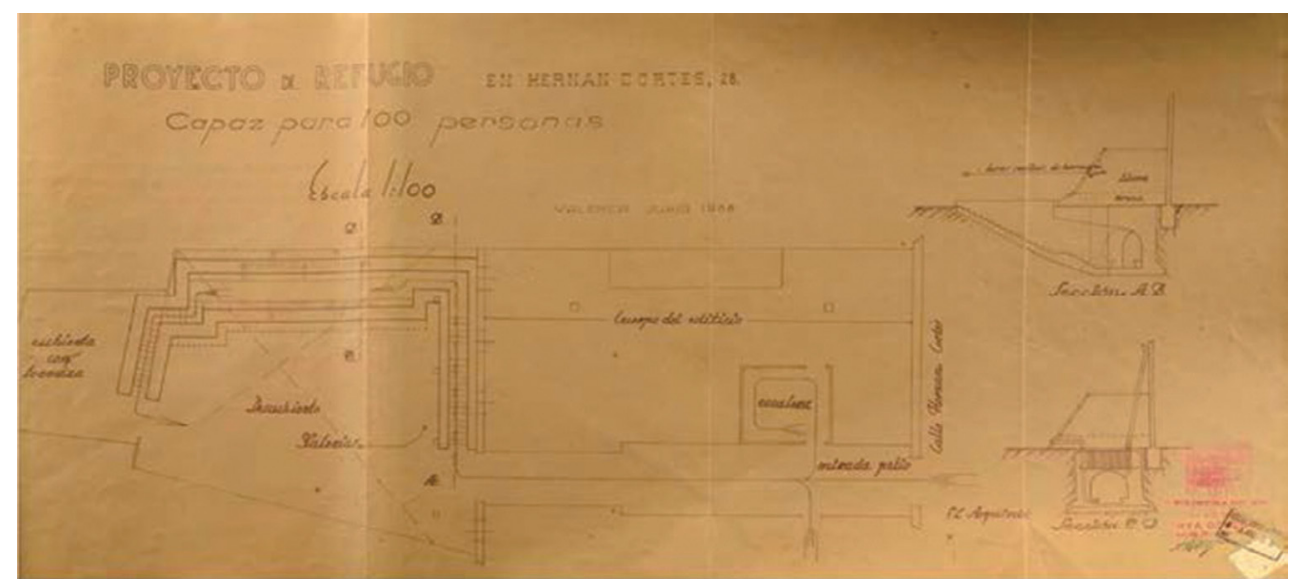

Figure 1: 'Project for an air-raid shelter at 28 Hernán Cortés Street. Capacity for 100 people'. Ordered by the Provincial Transport Union-UGT. Architect: Ramón Liern. Municipal and Historical Archive of Valencia (MHAV), Expansion 1938, box 1, file 12362 RG. Photograph: Mateo Gamón.

the defenceless population. The Passive Defence Committee carried out an important task with the construction of 43 public air-raid shelters and a hundred basement settings, with a total budget of 8.5 million pesetas ( $€ 51.086)$.

The Passive Defence Committee, created by the Ministry of National Defence on 22 June 1937, published a leaflet setting the guidelines for the construction of shelters and providing graphic plans with details of their main features. Therefore, new shelters were built following the specified model and adapted to the measurements of the chosen sites; this way, the same model was used for all the shelters built in schools. Regarding private shelters, types varied; the constructive solutions were different depending on the features of the ground and the building where the shelter was incorporated.

The excavation required for the shelters was approximately four meters deep, and was undertaken without any previous archeological study, although the Valencian researcher Primitivo Gomez Senent gathered some data regarding materials during the digs and published his discoveries under the pseudonym Primigénius in the almanac Las Provincias in 1941, entitled 'Archeological Study of Shelters in Valencia' (pp. 487-492). The most interesting discoveries were obtained from the shelters on Serranos Street and the one in the gardens of the Generalitat, which have disappeared today. He noted the existence of one shelter in the courtyard of the convent of Santa Catalina of Sena, which has disappeared today, in the site occupied by an important commedial gallery on Pintor Sorolla Street.

\subsection{Location}

As far as the location of shelters is concerned, there was no explicit plan to distribute them. Most of them were placed in existing buildings after residents' applications (Fig. 1). However, the new and isolated shelters were built in the playgrounds of existing school centres, in a few cases under buildable sites (Alta-Ripalda Street, Serranos-Palomino Street, Espada Street, University Street) or under public streets (Gran Vía, 14th of April Av., Church Square, in the neighbourhood of Campanar and Ruaya Street). 
The distribution of shelters was not homogeneous, but most of them were concentrated in the centre of the city, which sparked strong complaints through a letter to the head of the Ministry of Public Works, in 1937, in the pages of Fragua social, written by the residents of the Monteolivete neighbourhood:

and given the slow works of the various shelters in this city, as well as the neglect of working neighbourhoods, which are often the most punished areas by air raids ... we have seen with disappointment that, whereas in the most central streets where buildings have more strength - and at the same time and because of [...], the capitalist class is well protected - air-raid shelters have been constructed and go on being constructed, although working neighbourhood shelters could have been delayed because of the causes pointed out. (Fragua Social, Sunday, 28 February 1937)

The number of shelters was low in the most bombed area of the harbour of Valencia, because this part of the city was evacuated due to the danger. Moreover, the groundwater level in this area prevented deep digging, so the protective works were reduced to avoid the shrapnel at ground level.

In the terrible scenario after the bomb attacks, air-raid shelters and their unmistakable signs became singular landmarks in the degraded landscape of the city at war.

\subsection{Numbers}

As mentioned above, there is no official list of built shelters, due to the difficulty of controlling ongoing works, which was even more challenging during an extended period of war. However, several partial lists have been found - some even handwritten - revealing the general interest in the organization of defence. The official and most complete list of shelters was published in the newspaper Fragua Social on 11 February 1937, where seventy four shelters were precisely identified in different buildings of the city, many of them in existing basements.

The data collected for the present research came not only from the Municipal Archive, but from studies which in some cases were provided by interested people. The number increased up to 270 built shelters, although many more might have been built. The most recent complete list was published in 2011 by Moreno and Muñoz [5].

\subsection{Classification}

The purpose of air-raid shelters was to buffer the effect of projectiles: on the one hand, they had to counteract direct action depending on the bomb's weight and the shrapnel produced by the explosion, and on the other hand, the shock wave had to be dealt with.

For this reason, in all cases, a protection layer made of two or more levels of concrete cells was constructed to work as a shock absorber. The cells were sometimes filled with sand and occasionally with seaweed to increase the effect. Under this layout, a reinforced concrete slab of minimum $70 \mathrm{~cm}$ thick was built. Two other indispensable features for the safety of shelters are the position of the doors, which should number at least two and which should be located as far as possible, and artificial ventilation.

Valencian shelters have their own features, which are different from others in Spain, mainly due to their shallower depth and the extensive use of reinforced concrete. Their constructive 
systems follow two models: with vaulted and straight arches, with the latter system featuring concrete pillars to support the reinforced slab.

The vaulted model was the most common one in school shelters. It was designed for gardens and playgrounds, with basic measurements of $14 \times 28 \mathrm{~m}$, which could be adapted in different locations with small modifications. The model was totally subterranean, and access was gained through two ramps at opposite ends of the búnker, positioned in such a way that they were as separated as possible. The 2.40 -m-high nave was vaulted, and its interior had free passage space which was $2 \mathrm{~m}$ wide, with two long benches of $0.35 \times 0.35 \mathrm{~m}$, constructed of masonry along both sides of the nave. A storage area for air machines and two toilettes were added to the main space, and the drainage of the ramps was also installed.

A thick slab of reinforced concrete was constructed on the vault, and over the slab another cushioning layer made of concrete was added, finishing a flat roof at the street's same level.

This model has been found in several remaining shelters (Visitación Street, Pedro III el Grande Street, Jesús y María School, Cervantes School and Luis Vives High School) (Fig. 2). The two-nave model is the most common one, but there are others that include three, four or even seven naves, like in the old San Vicente Children's School, a site now occupied by a shopping centre, between Colon Street and Lauria Street.

As an example, the no-longer-existent shelter of Castellar had a section that was not completely covered, and its leaning roof was made of layers of sand and seaweed. Also, the bunker in Condes de Pestagua Square had two parallel and valuted naves, where the reinforced layers were situated over ground level, which were the same as the Gran Vía shelters, a few meters above ground level, because of the problems with the groundwater level. The concrete was later covered with a layer of tamped earth.

The straight arch model is made of a reinforced concrete slab supported by robust pillars. The access ramps are settled in the same way as the vaulted model, but occasionally replaced by stairs. The artificial ventilation system is always drawn in plans that are calculated in detail for large shelters.

A useful example are the shelters of Universidad (Fig. 5) and Encarnación Square, currently hidden, the one on Alta Street and the one next to the Rialto Cinema (Fig. 3), of which some photographs are preserved. In all these cases, the volume of the bunker's protective layers is recognizable over the ground level.

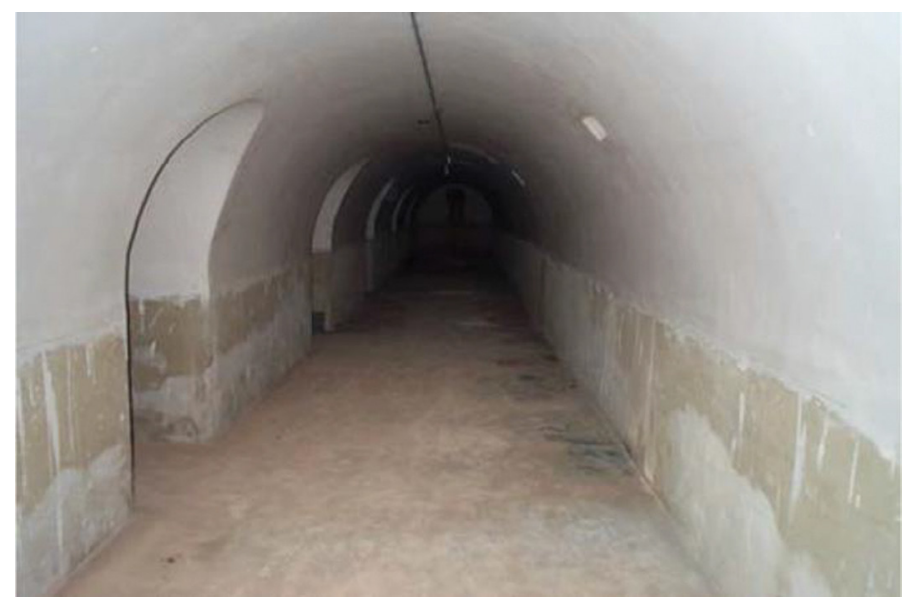

Figure 2: Air-raid shelter in Luis Vives high school. 


\section{PROY ECl0 of ATIIIII}

eil L plaza of emilio castelad

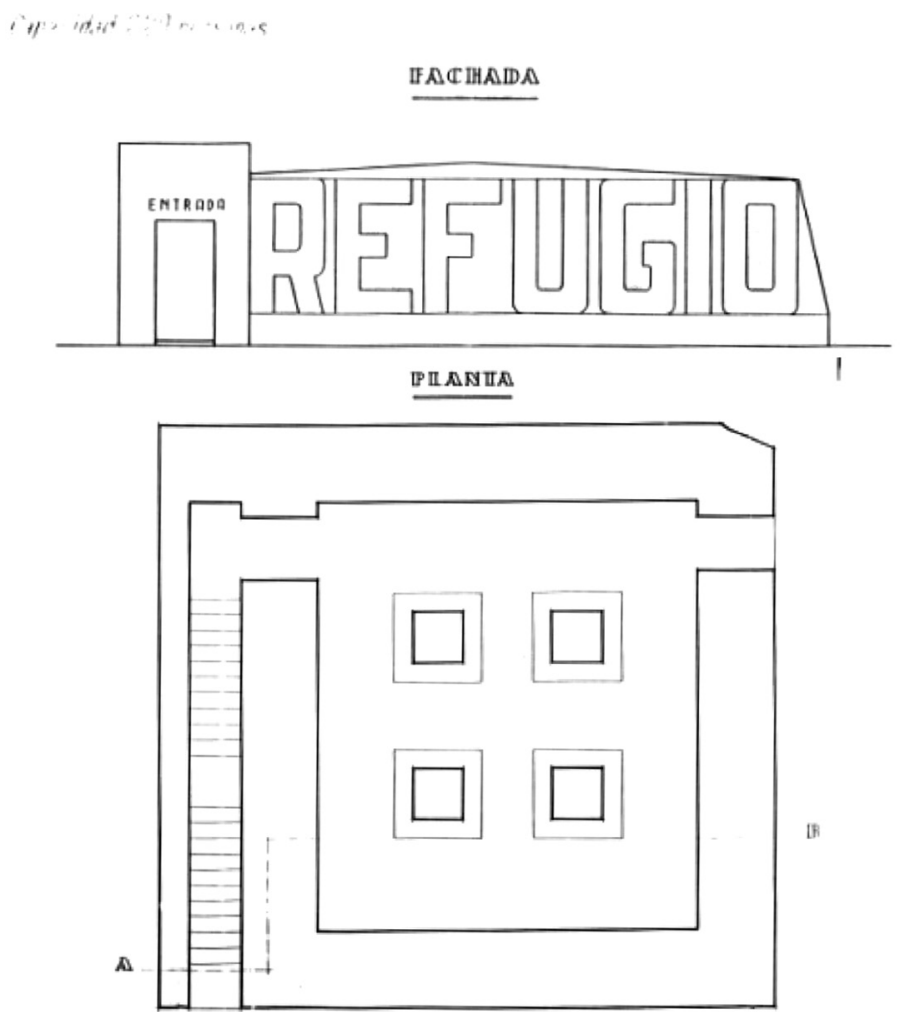

Figure 3: Elevation and plan of the no-longer-existent shelter, next to the Rialto Cinema, the basement staircase which was used as the mandatory second access to the shelter. (MHAV)

Both analysed models match new large-sized public shelters. However, there are additional private shelters of different shapes, sizes and protection systems, built in city block courtyards or dug under the existing buildings, always with the presence of ventilation systems and emergency exits.

The shelters named for grapeshot purposes are mere protective reinforcements over the basement of existing buidings, for example in the building La Unión y el Fénix, in the corner of Marques de Sotelo and Játiva Street (Fig. 4) and the building of Banco Vitalicio in Marqués the Sotelo and Periodista Azzati Street.

\subsection{The remains}

Currently, the existing remains of shelters are numerous, but visiting them is difficult because the majority of them are in private buildings whose landlords do not know about their existence or because they have been definitively closed. On the other hand, a few of them are 


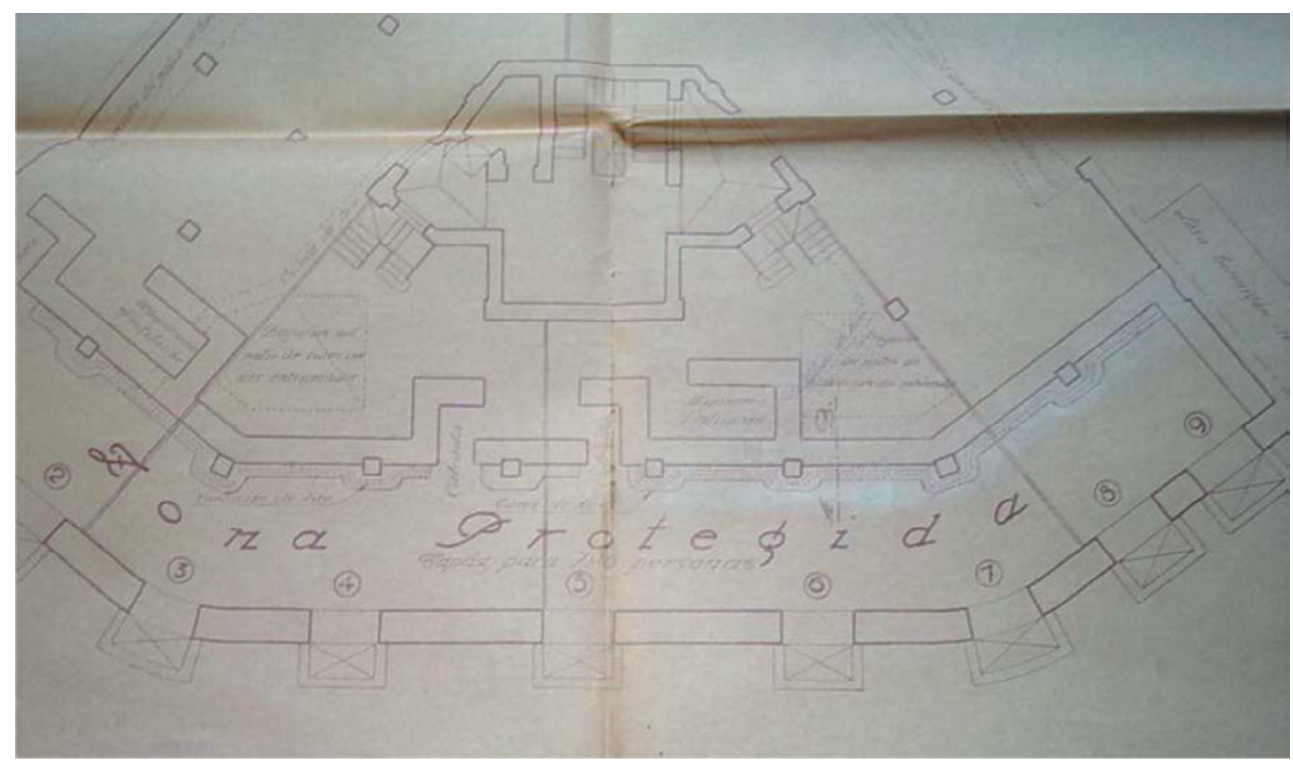

Figure 4: Plan with a grapeshot shelter area in the basement of the El Fenix building.

located on public sites and it was possible to enter them and record their main features, which are briefly described below.

1. The shelter at Alta-Ripalda Street was abandoned for a long time and was used by homeless people in the 1950s. After the River Turia Flood in 1957, it was refurbished by a falla festivity group that removed the mud, cleaned it and replaced the pavement. The inner space is a rectangle supported by nine central columns and is in a good state of preservation. The air chimneys can be seen from outside, where the top surface is currently a terrace.

2. The Serranos-Palomino shelter was calculated for 400 people and is supported by rectangular columns, the basement of which was used for benches. The entrance was far away from the interior space, where the shelter sign is preserved and is still readable (Fig. 6 ).

3. The shelter Condes de Pestagua Square is located only one metre under the ground level, due to the groundwater level of the area. The roof is unique, made of curved tiles, being the only known case, and includes many air chimneys. Inside, there are two 3-m-wide round arch-vaulted naves, where the marks of the wooden framework can be seen. It has been used by a falla festivity group for more than 50 years, although the sorroundings have been degraded.

4. The shelter located on Espada Street has features that link it to the shelter on Alta Street (Fig. 7), although its poor state of preservation prevents it from being visited. Planned for 380 people, no more information about this project has been found. It nedeed to be advertised with two signs, one over a facade in Tetuan Square, due to its nearly hidden location.

5. The Gran Asociación School shelter (on Padre Huérfanos Street) was placed next to the buiding gardens, at ground level (not underground) and became part of the building as a changing room and other types of rooms in the school. It is formed by two ten-metrelong vaulted naves which were $5.5 \mathrm{~m}$ wide and was protected by an upper level that may 


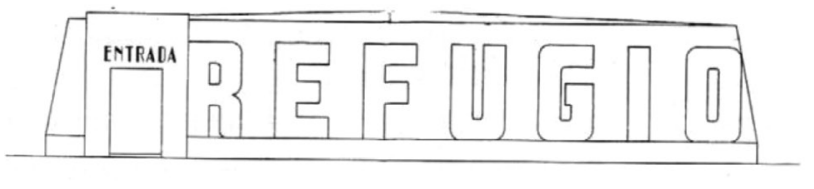

$S E C O C I O N$
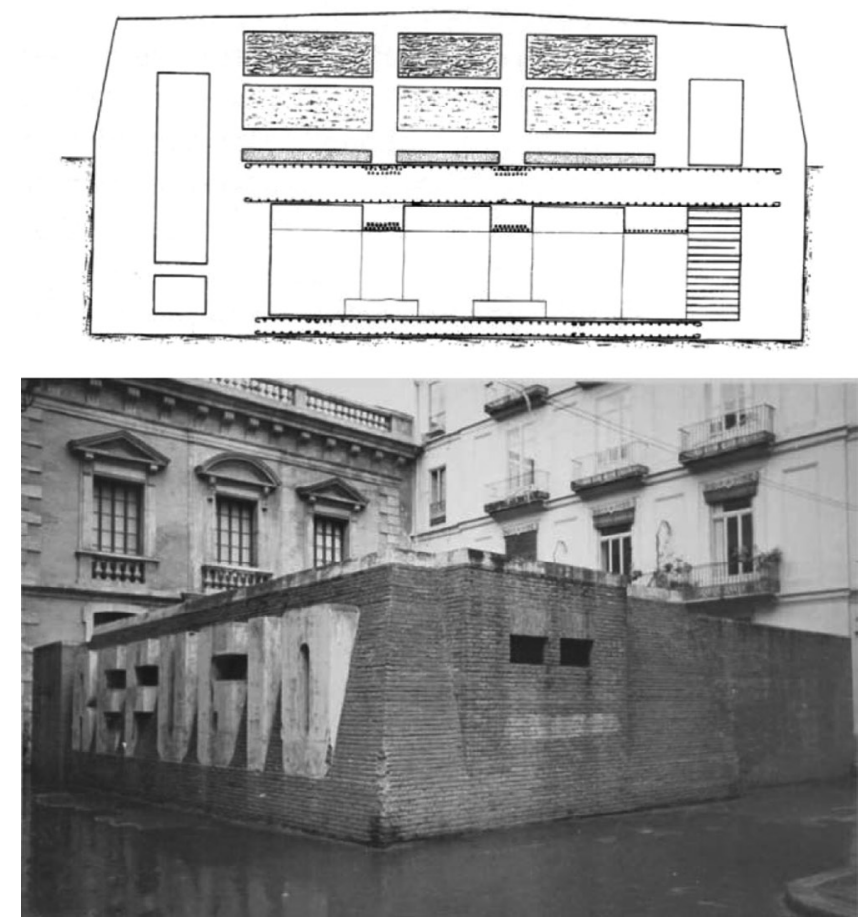

Figure 5: Elevation and section of the straight arch model, like the one which no longer exists in University Square (MHAV).

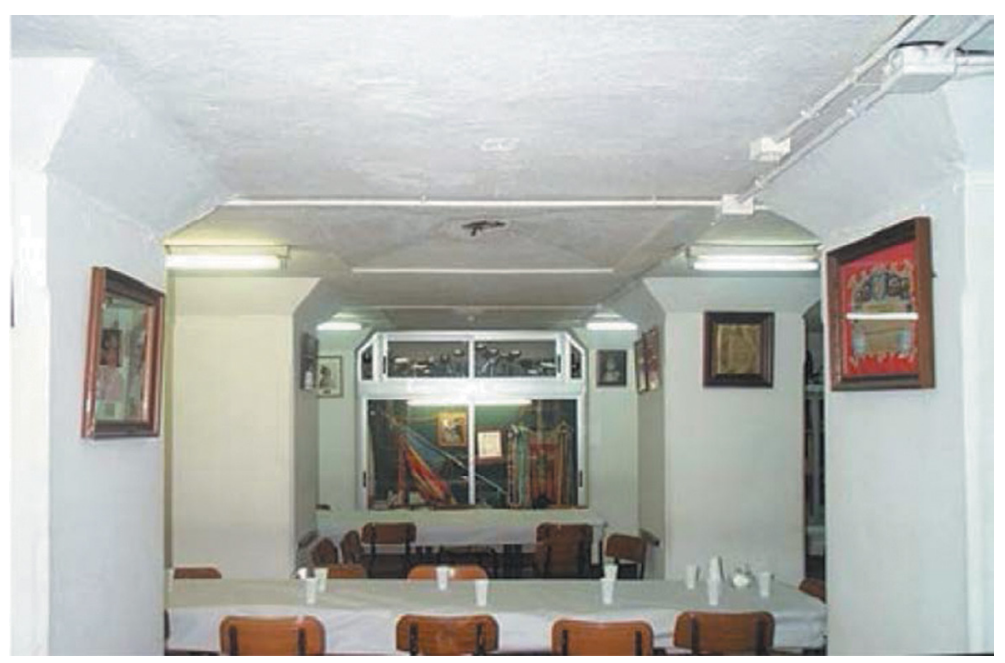

Figure 6: Interior of air-raid shelter in Serrano-Palomino Street. 


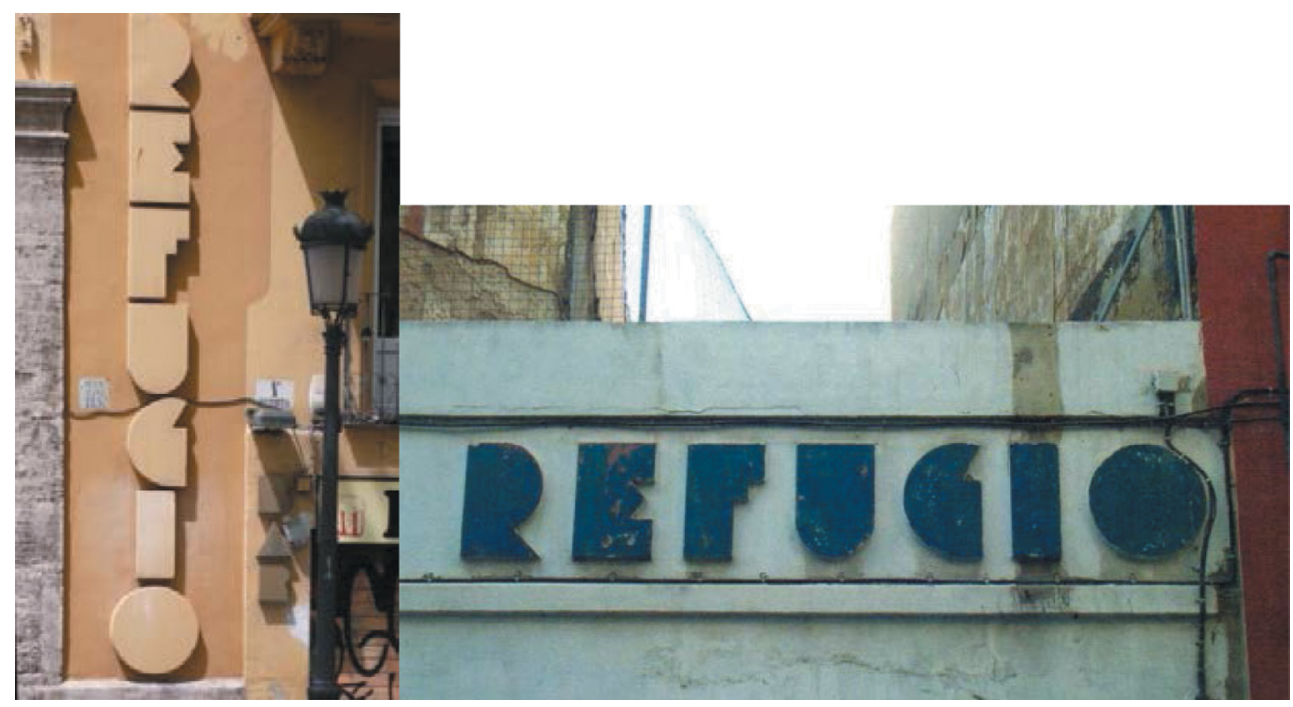

Figure 7: Remains of shelter signs on Espada and Serrano Street.

prove that the shelter was incorporated into an existing enclosed area of the school, next to the famous Racionistas Hall, designed by Joaquín Ma Arnau in 1880. Its current look, totally renovated for new activities, does not show the finishing materials of the original construction.

6. The shelters in Gran Vía are not apparent from outside, since their access has been covered and there is no information about them in the Municipal Archive. However, their locations are accurately defined in the Plan of the Township of Valencia, drawn from 1929 to 1944 by the General Directorate of the Geographical and Cadastral Institute, and were used by local administration services until the 1950s (Fig. 8). In that plan, comprised of 128 pages, there are a number of shelters drawn, among which are those along Gran Via. The shelter in Gran Via Germanías, in the middle of the road, appeared during the underground works in 2007.

In the same district, in the expansion zone of the city, other two shelters have been found, one on Jorge Juan Street and Conde Salvatierra Street and the other on Ruzafa Street and
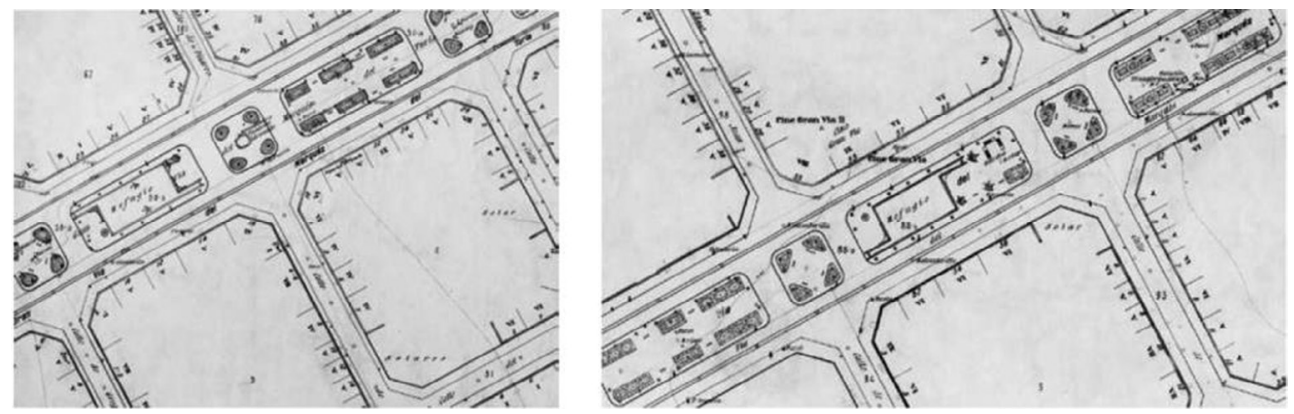

Figure 8: The air-raid shelters on Gran Vía Marques del Turia in the Plan issued by the General Directorate of the Geographical and Cadastral Institute. 
Pizarro Street. Regarding the first one, some photographs are kept in the archive of the Church of San Andres, since the parish used to celebrate mass while the new church on Colon Street was being constructed. The pictures show that the ramps were totally covered and the exterior's protective layer was only made of earth over a reinforced concrete slab.

7. The shelter in Luis Vives High School is the largest among the existing shelters, and it has been maintained in a good state of preservation. It is formed by four vaulted naves in a rectangle of $13.78 \times 33.50 \mathrm{~m}$, not including the ramp space. The vaults have a diameter of $2.67 \mathrm{~m}$, separated by $1 \mathrm{~m}$ between them. The access ramps were buried and replaced by a staircase in the last refurbishment of the school in the 1970s when it began to be used as a storage space; the long benches were demolished, the walls were plastered and painted, and a new lighting system was installed. Currently, this is the only visited shelter in the city.

8. The Balmes shelter is the typical school model shelter, constructed in the playgroud of Balmes School in Maestro Aguilar Street and had a capacity for 1,000 people. The detailed finishing of the benches is outstanding, with the edges covered by a strip of wood. It can currently be visited (Fig. 9).

Among the small-sized shelters, there still remains one in the Palace of Benicarló, today the Palace of Las Cortes, where the Republic's Government was set and used it as an archive but with its original characteristics. And the shelter in Asilo de Lactancia, restored a few years ago, is currently part of a thermal water spa, which makes it difficult to research.

Until a few years ago, the shelter in the García Lorca school had stood in the block courtyard of the current Juan de Dios Montañes school, with an entrance on Pedro III el Grande Street, but in September 1999 it was demolished during the construction of an underground car park.

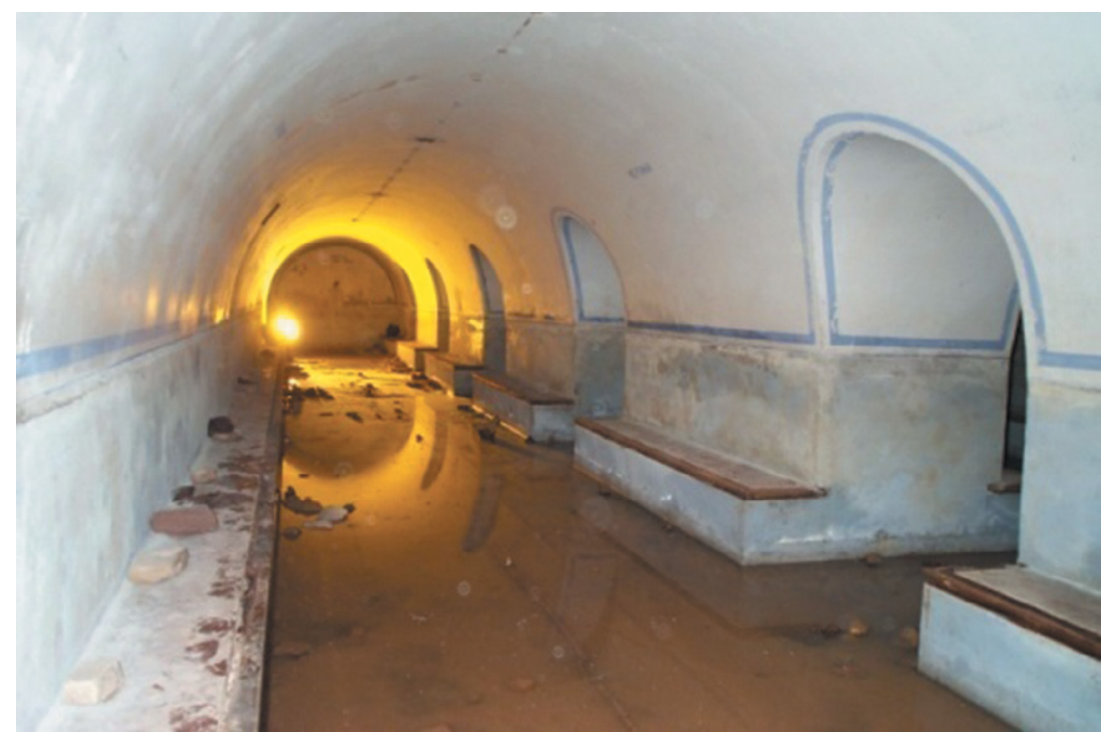

Figure 9: The Balmes shelter, discovered in 2004, where the original features of the school shelter are well preserved. 
9. The shelter on Ruaya Street has one vaulted central space divided in three naves, preserving a frieze of blue flowers and a cartoon of Mickey Mouse in each wall, in order to make it a space familiar to children, who in fact use it regularly. There is also a smaller space, one nave, on the north side with a bench along both walls, and two more small rooms, a toilet with tiles on the walls and a kitchen built afterwards, when the shelter was used as a flat.

10. Shelters of the post-war period. Air-raid construction continued after the war. In the Municipal Archive of Valencia there are several building projects after 1939 with new shelters included. Moreover, in the Encyclopaedia of Construction, by Joaquín Soto Hidalgo and published in Madrid in 1943, the author mentioned in the third volume a decree regarding the construction of shelters in cities of more than 20,000 inhabitants.

\subsection{Measures of protection: The heritage catalogue of Valencia}

In February 2015, twelve air-raid shelters and one bunker were listed in the Heritage Catalogue of the city of Valencia, and were attributed integral protection, considering their cultural interest due to their typology, history and archaeology. Their protection and impact on the surroundings was defined and a future use was proposed for each one (Fig. 10).
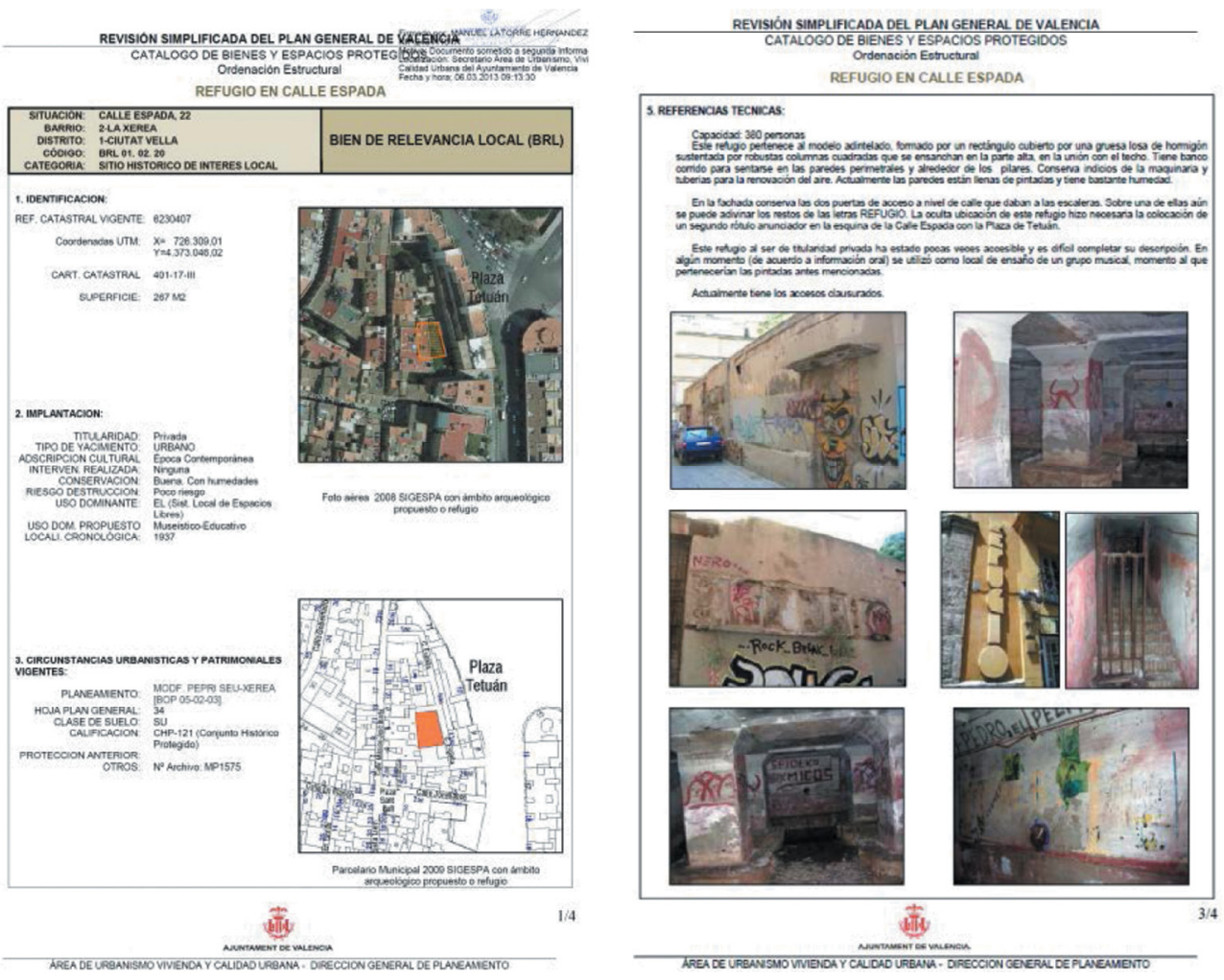

Figure 10: Index cards from the Valencian Heritage Catalogue where protection measures are established for the shelter on Espada Street. 
Integral protection means that only works of restoration and conservation will be admitted for the maintenance or reinforcement of the structural elements, as well as the improvement of the general state or facilities of the building.

However, the replacement or reconstruction of those primitive bodies and hollows can also be authorized when they benefit the city in terms of their cultural value, using always contemporary technical and constructive solutions in order to maintain the original design, using finishing solutions that enable distinguishing the reconstructed parts from the original ones. In addition, exceptional works for the redistribution of the inner space without altering the structural or outer features of the building are also allowed, when and if they do not damage the protected values nor they affect the constructive elements to be preserved.

Regarding the reuse of the shelters, the catalogue establishes a new educational museum standard for eleven of them and a general cultural use standard for one. Nevertheless, taking

Table 1: List of air-raid shelters included in the Valencian Heritage Catalogue, with reuse management impact indicators: location, property, current use, regulatory use and state of preservation.

\begin{tabular}{|c|c|c|c|c|c|}
\hline $\begin{array}{l}\text { District list } \\
\text { number }\end{array}$ & Location & Property & $\begin{array}{l}\text { Current use } \\
\text { building/plot }\end{array}$ & $\begin{array}{l}\text { Proposed use in } \\
\text { the catalogue }\end{array}$ & $\begin{array}{l}\text { State of } \\
\text { preservation }\end{array}$ \\
\hline $01 / 02$ & Alta-Ripalda St. & Public & $\begin{array}{l}\text { Ludic- } \\
\text { Leisure }\end{array}$ & $\begin{array}{l}\text { Museum- } \\
\text { educational }\end{array}$ & Good \\
\hline $01 / 20$ & Espada St. & Private & $\begin{array}{l}\text { Open space- } \\
\text { Courtyard }\end{array}$ & $\begin{array}{l}\text { Museum- } \\
\text { educational }\end{array}$ & $\mathrm{Bad}$ \\
\hline $01 / 29$ & $\begin{array}{l}\text { Padre Huérfanos St. } \\
\text { Gran Asociacion } \\
\text { school }\end{array}$ & Private & Education & $\begin{array}{l}\text { Museum- } \\
\text { educational }\end{array}$ & $\begin{array}{l}\text { Original } \\
\text { configuration } \\
\text { modified }\end{array}$ \\
\hline $01 / 44$ & $\begin{array}{l}\text { Luis Vives } \\
\text { High School }\end{array}$ & Public & Education & $\begin{array}{l}\text { Museum- } \\
\text { educational }\end{array}$ & Good \\
\hline $01 / 47$ & Serranos St. & Public & None & $\begin{array}{l}\text { Museum- } \\
\text { educational }\end{array}$ & Good \\
\hline $02 / 13$ & $\begin{array}{l}\text { Germanías- } \\
\text { Marqués del Turia } \\
\text { Gran Vía }\end{array}$ & Public & Garden & Cultural & Good \\
\hline $02 / 26$ & Balmes School & Public & Education & $\begin{array}{l}\text { Museum- } \\
\text { educational }\end{array}$ & $\begin{array}{l}\text { Good, with } \\
\text { dampness }\end{array}$ \\
\hline $03 / 03$ & $\begin{array}{l}\text { Jesús y María } \\
\text { School }\end{array}$ & Public & Education & $\begin{array}{l}\text { Museum- } \\
\text { educational }\end{array}$ & $\begin{array}{l}\text { Good, with } \\
\text { dampness }\end{array}$ \\
\hline $05 / 12$ & Ruaya St. & Public & None & $\begin{array}{l}\text { Heritage- } \\
\text { museum }\end{array}$ & $\begin{array}{l}\text { Good, with } \\
\text { dampness }\end{array}$ \\
\hline $05 / 16$ & S.Trinidad Convent & Private & Religious & $\begin{array}{l}\text { Museum- } \\
\text { educational }\end{array}$ & Good \\
\hline $05 / 17$ & Libertad School & Private & Education & $\begin{array}{l}\text { Museum- } \\
\text { educational }\end{array}$ & Good \\
\hline $11 / 02$ & $\begin{array}{l}\text { El Grao } \\
\text { High School }\end{array}$ & Public & Education & $\begin{array}{l}\text { Museum- } \\
\text { educational }\end{array}$ & Unknown \\
\hline
\end{tabular}


into account other factors which are influential in the urban management needed to obtain reuse certification, such as location, property, current use and state of preservation (Table 1), looking for the shortest process and the lowest public investment, some shelters are the most suitable ones for the implementation of a museum, because they are public property, free of expropriation, as well as not being currently used, and the cost of refurbishment works would not be excessive.

Therefore, it could be a good option to choose the shelters on Serrano Street, Gran Vía or Ruaya Street to set up a museum, but without prejudice of opening other public shelters for occasional public guided tours, as is being done by the teachers of the Luis Vives High School.

\section{CONCLUSIONS}

The air-raid shelters form part of a historical period of the life of Valencia. The fact that they were not demolished after the war has caused them to remain in the collective memory of people over seventy years old. The city's Art Deco signs have been for a long time silent witnesses of a war period that deeply affected the city and must be preserved as part of the city's historical landscape.

The preservation and valuation of shelters, as a historical legacy, is an urgent need, so it is convenient to establish measures of protection [7].

When part of the heritage catalogue of Valencia was reviewed in May 2013, a dozen airraid shelters were protected as Local Relevant Interest Assets. With this recognition, a new stage began in terms of the preservation of this important defence heritage, which should be stepped up in the future.

However, the task has not been finished, as the protection catalogue must be completed, and moreover, the dissemination works must begin: the location of the old school shelters, under the playgrounds, does not make them suitable for public use, since they currently belong to religious institutions. But some shelters, because of their dimensions and good state of preservation, could be useful spaces for prospective museums.

In fact, any mentioned shelter could be reused as a small museum to honour the events lived by the city of Valencia during the Civil War, as some objects of this period could be shown, through films and sound recordings, in order to complete a suitable scene that would bring to light a nearly forgotten period, when Valencia was the capital of the nation.

\section{REFERENCES}

[1] Santacana, J., Entre l'oblit y la memoria: el patrimoni de la guerra, Revista EBRE 38, Revista Internacional de la Guerra Civil (1936-1939), 2, Universitat de Barcelona, 2004, http://www.raco.cat/index.php/Ebre/article/view/39920.

[2] González, J. \& Navajas, O., Ley de Memoria Histórica: estrategias para recuperar y comunicar el patrimonio de la Guerra Civil Española, Revista EBRE 38, Revista Internacional de la Guerra Civil (1936-1939), 6, Universitat de Barcelona, 2011, http:// www.raco.cat/index.php/Ebre/article/view/250291.

[3] Alonso, P., Reflexiones en torno a una Arqueología de la Guerra Civil: el caso de Laciana (León, España), MUNIBE (Antropologia-Arkeologia), 59, San Sebastian, 2008, http:// www.aranzadi.eus/fileadmin/docs/Munibe/2008291312AA.pdf. (ISSN 1132-2217).

[4] National Plan of Defence Architecture. Paragraph 1.4. Conference on Spanish Castles and Defence Heritage Guidelines, in Baños de la Encina (Jaen), September, 2006. 
[5] Moreno, M. \& Muñoz, A., Arqueologia de la memòria: els refugis antiaeris a la ciutat de València, SAGVNTUM, 43, Universitat de València: València, 2011, DOI: 10.7203/ SAGVNTVM.43.326.

[6] Taberner, F., The Passive Defence. Notes About the Construction of the Air-Raid Shelters of Valencia City. II Congreso de Historia de la Ciudad de Valencia, Universidad de Valencia: Valencia, 2015.

[7] Taberner, F. \& Broseta, MT., Los refugios antiaéreos de Valencia: del olvido a la Relevancia Local, Arche, 8-9, Instituto de Restauración del Patrimonio, Universidad Politécnica de Valencia, 2015, http://www.irp.webs.upv.es/documents/arche_article_280.pdf.

[8] Aragó, L., Azkárraga J.M. \& Salazar, J., Valencia 1931-1939. Guía urbana. La ciudad en la Segunda república. Universidad de Valencia: Valencia, 2007.

[9] V. Deleito, A. \& V. Deleito, J., Defensa antiaérea republicana (1936-1939. Artillería y refugios...Algo de Valor, Ediciones de Investigación Requena: Valencia, 2000.

[10] Llopis, A. \& Perdigón, L. Cartografía Histórica de la ciudad de Valencia (1608-1944), Universidad Politécnica de Valencia: Valencia, 2010. 